\title{
Genetic control of pulp and timber properties in maritime pine (Pinus pinaster Ait.)
}

\author{
David Pot ${ }^{\mathrm{a}^{*}}$, Guillaume Chantre ${ }^{\mathrm{b}}$, Philippe Rozenberg ${ }^{\mathrm{c}}$, José Carlos Rodrigues ${ }^{\mathrm{d}}$, \\ Gwynn Lloyd Jones ${ }^{\mathrm{e}}$, Helena Pereira ${ }^{\mathrm{d}}$, Björn Hannrup ${ }^{\mathrm{f}}$, Christine Cahalan ${ }^{\mathrm{g}}$ \\ and Christophe Plomion ${ }^{\mathrm{a}}$
}

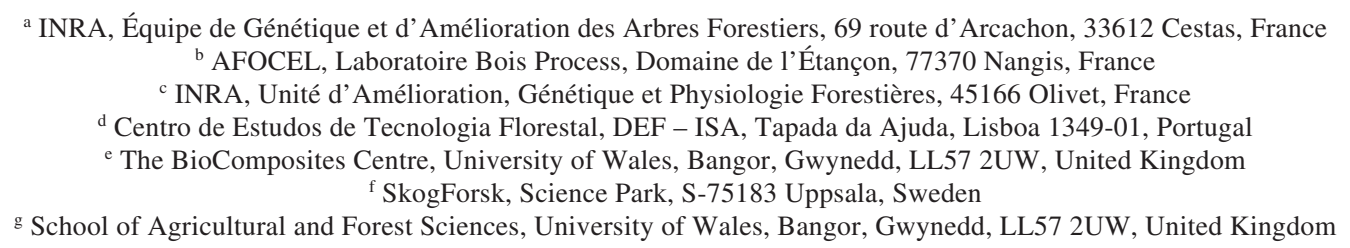

(Received 16 August 2001; accepted 28 March 2002)

\begin{abstract}
Wood is one of our most important natural resources and has been exploited for many hundreds of years as fuel, building material and a source of paper. Its composition is variable among and within species. The ability to monitor the intra-specific variability is a prerequisite to improve wood and end-products properties. This paper describes a study of the genetic control of a large set of wood properties, including growth, timber quality traits, wood chemical composition, kraft pulp production parameters and pulp properties, in a $12 \times 12$ half diallel of maritime pine (Pinus pinaster Ait.). While relatively high $\left(\mathrm{h}_{\mathrm{ns}}^{2}>0.3\right)$ narrow-sense heritabilities were observed for density heterogeneity, lignin content, alpha-cellulose content and coarseness, no significant genetic effect was detected for hemi cellulose, water extractives, kraft pulp production parameters and pylodin. Slightly lower heritabilities $\left(0.15<\mathrm{h}_{\mathrm{ns}}^{2}<0.3\right)$ were also obtained for wood density and fibre properties (length, width, curl, zero span). As a consequence and considering the phenotypic coefficient of variation obtained for these traits, improvement by selection of trees with outstanding wood quality is feasible. Nevertheless, it seems obvious that wood quality breeding can not be done without taking into account growth, and the only way to manage this constraint (negative correlation between growth and density) will be the constitution of elite "wood quality" populations in a already growth improved genetic population.
\end{abstract}

wood quality / heritability / genetic correlation / tree breeding / Pinus pinaster Ait.

Résumé - Déterminisme génétique des propriétés du bois impliquées dans la production papetière et la qualité du bois d'œuvre chez le Pin maritime (Pinus pinaster Ait.). Le bois, une des ressources naturelles les plus importantes, est exploité depuis des centaines d'années comme combustible, matériau de construction et source de papier. Sa composition est très variable, non seulement entre espèces mais aussi au niveau intra spécifique. La compréhension de cette variabilité intra spécifique est un pré-requis de l'amélioration des propriétés des produits à base de bois. L'objectif de l'étude présentée ici est la compréhension du déterminisme génétique de plusieurs caractères impliqués dans la composition chimique et les propriétés du bois (caractéristiques physiques, paramètres de production industrielle et propriétés de la pâte) grâce à l'étude d'un demi diallèle $12 \times 12$. Bien que des héritabilités au sens strict relativement élevées $\left(\mathrm{h}_{\mathrm{ns}}^{2}>0,3\right)$ aient été obtenues pour l'hétérogénéité de la densité, les contenus en lignine et en alpha-cellulose et la masse linéique, aucun effet génétique significatif n'a été mis en évidence pour le contenu en hémi-cellulose, les extractibles, les paramètres de production de pâtes kraft, et la densité estimée grâce au pilodyn. Des héritabilités plus faibles $\left(0,15<\mathrm{h}_{\mathrm{ns}}^{2}<0,3\right)$ ont quant à elles été obtenues pour la densité du bois et les propriétés des fibres (longueur, largeur, courbure, rigidité). En conséquence, considérant les coefficients de variation phénotypiques obtenus pour ces caractères, des gains génétiques significatifs peuvent être attendus. Néanmoins, l'amélioration des propriétés du bois ne pourra pas se faire sans prendre en compte la croissance. Le seul moyen de gérer cette contrainte (induite par des corrélations négatives entre croissance et densité) sera la constitution de populations élites pour la qualité du bois au sein de bases génétiques déjà améliorées pour la croissance.

qualité du bois / héritabilité / corrélation génétique / amélioration / Pinus pinaster Ait.

* Correspondence and reprints

Tel.: 05571228 85; fax: 05571228 81; e-mail: pot@pierroton.inra.fr 


\section{INTRODUCTION}

Wood can be regarded as a natural composite material consisting of flexible tubes of cellulose bonded together and held rigid by lignin. However, this simple definition hides the fact that wood is also highly complex and variable, not only in its chemical composition but also at the anatomical level (e.g. tracheid morphology). This variability, which occurs not only between species, but also within a species and even within a single tree, is double-edged. On the one hand it allows wood to be utilised for many kinds of products (papers, building materials, chemicals, energy, etc.), but on the other hand it compromises its performance in each application. The understanding of this variability and our ability to use it are of key importance in order to improve the end-use products.

Maritime pine (Pinus pinaster Ait.) is an important commercial species in southwest Europe. It is the primary coniferous species in France in terms of planted area (1.4 million ha) and harvest yield ( 8.3 millions $\mathrm{m}^{3}$ per year). Its wood is used in both the timber and pulp industries, involving different partners (forest owners, timber and pulp industrials) for whom different traits may be of interest. Today, the maritime pine breeding programme has achieved its third generation of selection. Genetic gain of improved varieties is about $30 \%$ for both volume and straightness. The introduction of wood quality selection criteria is now considered as an important objective of the breeding programme. Such selection is however hampered by the lack of information for wood quality traits, not only at the genetic but also at the industrial levels.

Wood quality can only be defined in terms of particular end use, and may involve several traits (e.g. density, wood heterogeneity, wood chemical composition and fibre properties). Mean density is acknowledged to be the best single predictor of wood mechanical properties [1, 36, 41, 43, 48, 67]. Fairly strong positive correlations between modulus of elasticity (MOE), a basic mechanical property of softwoods, and density have often been reported (for review see [54]). But, in spite of its key importance, mean density is not the only trait involved in wood mechanical properties. Larson [33] stated that the greatest wood quality problems facing all wood-using industries is lack of uniformity. With respect to density, according to Megraw [38], "the greatest variability in specific gravity occurs within each annual ring". Thus one of the targets of breeding for wood mechanical properties could be a decrease in density heterogeneity within individual rings. This modification might also affect pulp production if within-ring heterogeneity in density was associated with heterogeneity of chemical and fibre properties. It is assumed that wood density is positively linked to pulp yield (increasing density also increase the tonnage of dry fibre produced per unit area), and some pulp quality traits [9, 22, 25, 28]. Unfortunately, wood density alone is a poor indicator of other kraft pulp quality traits $[28,29]$. In order to estimate the "pulp potential" of a tree, it is important to take into account its fibre characteristics. Recent studies have shown that several fibre properties can have a pronounced influence on pulp yield and pulp quality $[16,25,27,68]$. The chemical composition (e.g. lignin, polysaccharides, extractives) must also be considered, these traits have direct consequences for production costs and final product quality.

Breeding trees to produce wood for a given wood processing industry is a complex problem. It is essential (1) to define which are the key properties influencing the quality of the product, (2) to estimate the possibilities of genetic improvement of these key properties and (3) to estimate the correlated response to selection for key properties of other targeted traits such as growth. In order to provide the background for initiating a breeding programme for wood quality in maritime pine, genetic parameters are being estimated for a large set of wood properties in a wide range of experimental designs (diallel, factorial and clonal tests). This paper describes a study of the genetic determinism of a large set of wood properties in a half diallel. Genetic parameters including heritabilities and genetic correlations are presented and a breeding strategy for the utilisation of maritime pine wood for timber and pulping purposes is discussed.

\section{MATERIALS AND METHODS}

\subsection{Experimental trial}

A $12 \times 12$ half-diallel was used to estimate the phenotypic variability and the genetic parameters (variance components, heritabilities and genetic correlations) of the studied traits. Parental trees were mated in 1980, seeds from the controlled crosses were sown in a nursery in spring 1982 and seedlings were planted in autumn 1982. The 12 parents were "plus trees", phenotypically selected for stem growth and straightness in the local provenance of the Landes de Gascogne. The half-diallel was located in Cestas (Gironde, France, $0^{\circ} 44^{\prime} \mathrm{W}, 44^{\circ} 44^{\prime} \mathrm{N}$ ) on a semi-humid podzolic soil. Spacing was $4 \mathrm{~m}$ between rows and $1.1 \mathrm{~m}$ between individual trees, i.e. 2272 trees/ha. The experimental design consisted of 74 incomplete randomised blocks. Each block comprised 16 plots of 4 trees. For the present study, 591 trees belonging to 73 families (without selfed crosses) were cut in March 1997 (when trees were 14 years old). The fact that 73 families were involved in the half-diallel (without selfed crosses) analysis instead of 66 was due to the low number of individuals for some families. Assuming that maternal effects were low at 15 years of age [18], some families from the opposite half-diallel were introduced in order to improve the power of our analysis. Each family consisted of eight individuals on average.

\subsection{Data measurement}

Five types of traits namely (1) growth, (2) timber quality traits, (3) wood chemical composition, (4) kraft pulp production parameters and (5) fibre properties were measured. For each trait, the number of individuals measured, the mean and the phenotypic coefficient of variation are given in table $I$.

Before felling, straightness (STR) was estimated as the deviation of the tree from verticality at $1.3 \mathrm{~m}$. This data is given in $\mathrm{cm}$, and increases with the divergence of the tree from verticality. At the same 
Table I. Definition, number of observations (n), mean value (mean) and phenotypic coefficient of variation $\left(\mathrm{CV}_{\mathrm{p}}\right)$ of the studied traits.

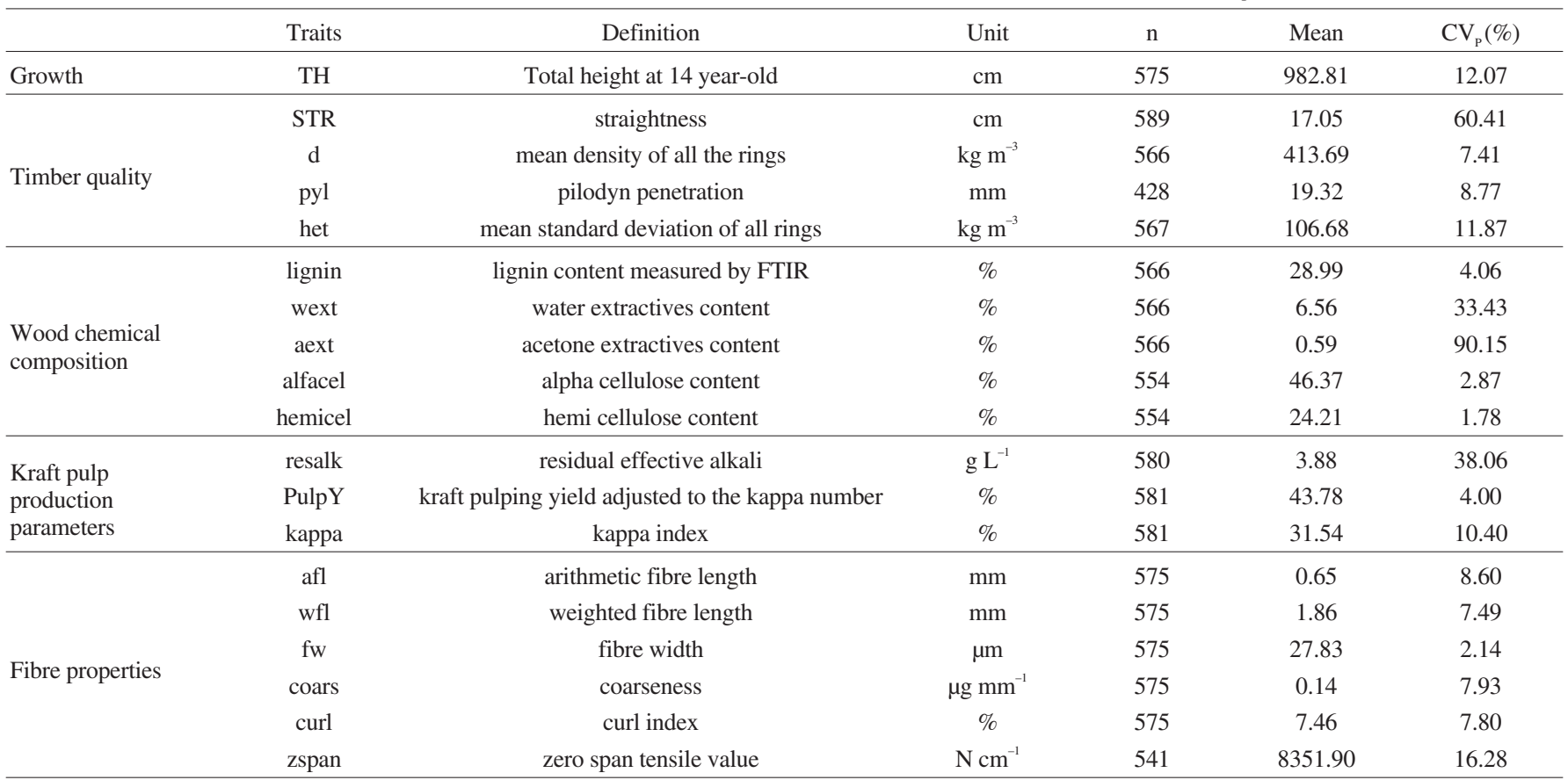

time, pilodyn pin depth of penetration (pyl), an indirect estimation of wood density [23], was measured at breast height under bark. In order to avoid compression wood, the pilodyn was applied on the opposite radii perpendicular to the prevailing wind direction. After felling, total height (TH) of each tree was recorded and three logs were cut above $1.3 \mathrm{~m}$ from the ground in order to minimise root system influences on characterization of wood properties.

The first $\log (7 \mathrm{~cm}$ in length) was used for detailed X-ray densitometry measurement using the method described by Polge [50]. The wood sample was chosen in order to avoid compression wood. Based on the X-ray microdensitometric profiles, mean (d) and heterogeneity of density (mean of ring standard deviation of density) (het) were calculated.

Wood chemical properties were estimated on the second log (10 cm in length). Two successive extractions were carried out on wood powder, first with water (wext) and then with acetone (aext) in order to quantify the proportion of extractable components (tannins, resins, fatty acids...). Lignin (lignin), hemicellulose (hemicel) and alpha cellulose (alphacel) contents of oven-dry extractive-free wood were predicted by using a calibration model relating FTIR (Fourier Transform Infrared spectroscopy) data with values obtained by traditional chemistry methods. The applied calibration and prediction procedure are reported by Rodrigues et al. [51].

The third contiguous $\log (40 \mathrm{~cm}$ in length) was turned into chips, stabilised in a controlled climate cell to a constant dry matter content of $89 \%$, and extracted according to the procedure described above. Then, samples were kraft pulped to kappa 30 in $150 \mathrm{~mL}$ digesters using the following cooking programme: 90 minutes from $20{ }^{\circ} \mathrm{C}$ to $170{ }^{\circ} \mathrm{C}, 90$ minutes at $170{ }^{\circ} \mathrm{C}$; white liquor $24 \%$ active alkali, $30 \%$ sulfidity, liquor/wood ratio of 4 . The residual concentration of $\mathrm{NaOH}$ in the black liquor after pulping, also called residual effective alkali (resalk), kappa index (kappa), used to assess the degree of delignification of the pulp kraft, and pulping yield adjusted (by covariance analysis) to the kappa index (PulpY) (\%) were measured.
After pulping, fibre characteristics were determined using PQM 1000 apparatus. Measurements were made on samples of $2 \mathrm{~g}$ of pulp (equivalent oven-dry weight). Fibre properties were arithmetic mean fibre length (afl), weighted mean fibre length (wfl) (which reduces the effect of small fragments of fibres), fibre width (fw), coarseness (coars) (a measure of mass per unit length of fibre) and curl index (curl) (measured as [real length/projected length-1] $\times 100$ which is an assessment of the straightness of the fibres). Finally average tensile strength of individual fibres (zspan) was derived from the measurement of the wet zero-span tensile value using TAPPI method: T273 pm-95 [59].

\subsection{Parameters estimation procedure: half-diallel analysis}

Genetic parameters were estimated using the DIOGENE software $[2,3]$.

In the first step, analysis of variance for block, family and block $\times$ family interaction effects derived from a "Henderson III" model [56] was carried out. Linear model assumptions were checked for each trait. When necessary, data were adjusted for the block effect, prior to the decomposition of the family effect (half-diallel analysis). In the second step, analysis of the half-diallel (selfed combinations were not considered) was carried out using the following random model:

$$
\mathrm{Y}_{\mathrm{ijk}}=\mu+\mathrm{a}_{\mathrm{i}}+\mathrm{a}_{\mathrm{j}}+\mathrm{s}_{\mathrm{ij}}+\varepsilon_{\mathrm{ijk}}
$$

where $Y_{i j k}$ is the value of the trait for the individual k corresponding to the cross between the male $\mathrm{i}$ and the female $\mathrm{j}, \mathrm{a}_{\mathrm{i}}\left(\mathrm{a}_{\mathrm{j}}\right)$ is the general combining ability (GCA) of the $\mathrm{i}$-th $\left(\mathrm{j}\right.$-th) parent, $\mathrm{s}_{\mathrm{ij}}$ is the specific combining ability (SCA) of the cross between the $\mathrm{i}$-th and the $\mathrm{j}$-th parent and $\varepsilon_{\mathrm{ijk}}$ is the residual term. The additive and dominance variances are: $\sigma_{\mathrm{A}}^{2}=4 \sigma_{\mathrm{a}}^{2}$ and $\sigma_{\mathrm{D}}^{2}=4 \sigma_{\mathrm{s}}^{2}$ and and the phenotypic variance is: $\sigma_{\mathrm{P}}^{2}=\sigma^{2}\left(\mathrm{Y}_{\mathrm{ijk}}\right)=\sigma_{\mathrm{a}}^{2}+\sigma_{\mathrm{s}}^{2}+\sigma_{\varepsilon}^{2}$. 


\subsection{Heritabilities}

Epistatic variance components were assumed to be small enough to be ignored and narrow (ns) and broad sense (bs) heritabilities were calculated as $\mathrm{h}_{\mathrm{ns}}^{2}=\sigma_{\mathrm{A}}^{2} / \sigma_{\mathrm{P}}^{2}$ and $\mathrm{h}_{\mathrm{bs}}^{2}=\left(\sigma_{\mathrm{A}}^{2} / \sigma_{\mathrm{D}}^{2}\right) / \sigma_{\mathrm{P}}^{2}$, respectively.

\subsection{Correlations}

Estimates of covariance between pairs of traits were derived from a multi-trait analysis of covariance. Subsequently the corresponding correlation estimates were calculated as follows:

$$
r_{x y}=\sigma_{x y} /\left(\sigma_{x} \cdot \sigma_{y}\right)
$$

where $\mathrm{x}$ and $\mathrm{y}$ indicate two different traits.

Accuracies of the estimates of genetic parameters were obtained by bootstrap analysis (1 000 samples for each parameter). The normality of the distributions obtained were checked and $95 \%$ confidence intervals $(\mathrm{CI})$ were calculated as $\mathrm{CI}=\mu \pm 1.96 \sigma$ (where $\mu$ is the mean and $\sigma$ the standard deviation of the parameter values obtained by bootstrapping).

\subsection{Breeding parameters}

Expected genetic gains (GG) were calculated for each trait (x) according to the following formula:

$$
\mathrm{GG}_{\mathrm{x}}=\mathrm{i} \cdot \mathrm{h}_{\mathrm{ns}}^{2} \cdot \sigma_{\mathrm{Px}}
$$

where $\mathrm{i}$ is the selection intensity; $\mathrm{h}_{\mathrm{ns}}^{2}$ is the narrow sense heritability and $\sigma_{\mathrm{p}}$ the phenotypic standard deviation of trait $\mathrm{x}$.

Selection for one trait $(\mathrm{x})$ will result in a correlated response of other traits, and the correlated response of a trait y can be estimated by using the equation of indirect response [17]:

$$
\mathrm{Cr}_{\mathrm{y} / \mathrm{x}}=\mathrm{i} \cdot \mathrm{h}_{\mathrm{x}} \cdot \mathrm{h}_{\mathrm{y}} \cdot \mathrm{rg}_{\mathrm{xy}} \cdot \sigma_{\mathrm{Py}}
$$

where $\mathrm{Cr}_{\mathrm{y} / \mathrm{x}}$ is the correlated response of trait $\mathrm{y}$ due to selection for trait $\mathrm{x}, \mathrm{h}_{\mathrm{x}}$ and $\mathrm{h}_{\mathrm{y}}$ are the square roots of appropriate narrow sense heritabilities for traits $\mathrm{x}$ and $\mathrm{y}$ respectively; $\mathrm{rg}_{\mathrm{xy}}$ is the additive genetic correlation between traits $\mathrm{x}$ and $\mathrm{y}$ and $\sigma_{\mathrm{py}}$ is the phenotypic standard deviation of trait $y$.

Finally, because of the high number of traits contributing to wood quality and the general requirement of forest tree users for multi-uses varieties instead of single-use ones, multi trait selection was examined according to the method presented by Lin [35].

\section{RESULTS}

\subsection{Phenotypic variation and decomposition of the genetic variance}

For each trait, descriptive statistics are given in table I. Total height (TH) and straightness (STR), the two selection criteria of the current maritime pine breeding programme showed moderate to high coefficients of phenotypic variation: 12.07 and $60.41 \%$, respectively. These results are consistent with those of previous studies in maritime pine [12, 31]. With the exception of extractives content (aext, wext), which exhibited high levels of phenotypic variation, the phenotypic coefficients of variation for wood quality traits were low (less than 10\%). This is consistent with most of the results reports in the literature [11, 30, 44, 45].

The model, including block and family, allowed us to detect significant genetic controls for thirteen of the nineteen

\begin{tabular}{|c|c|c|c|c|c|c|c|c|c|}
\hline \multirow{3}{*}{$\begin{array}{l}\text { Source } \\
\text { df } \\
\text { Traits }\end{array}$} & \multicolumn{3}{|c|}{ Block } & \multicolumn{3}{|c|}{ Family } & \multicolumn{3}{|c|}{ Family $\times$ Bloc } \\
\hline & \multicolumn{3}{|c|}{73} & \multicolumn{3}{|c|}{72} & \multicolumn{3}{|c|}{201} \\
\hline & $\mathrm{F}$ & $P$-value $(\%)$ & $\mathrm{r}^{2}(\%) *$ & $\mathrm{~F}$ & $P$-value $(\%)$ & $\mathrm{r}^{2}(\%) *$ & $\mathrm{~F}$ & $P$-value $(\%)$ & $\mathrm{r}^{2}(\%)^{*}$ \\
\hline TH & 3.96 & $0.00 \mathrm{~s}$ & 37.99 & 2.48 & $0.00 \mathrm{~s}$ & 24.44 & 1.73 & $0.01 \mathrm{~s}$ & 27.16 \\
\hline STR & 1.06 & $36.71 \mathrm{~ns}$ & 12.16 & 3.03 & $0.00 \mathrm{~s}$ & 35.70 & 1.05 & $37.47 \mathrm{~ns}$ & 32.50 \\
\hline d & 1.06 & $37.44 \mathrm{~ns}$ & 13.93 & 1.88 & $0.02 \mathrm{~s}$ & 25.45 & 1.02 & $46.13 \mathrm{~ns}$ & 37.36 \\
\hline het & 1.29 & $8.02 \mathrm{~ns}$ & 15.02 & 2.76 & $0.00 \mathrm{~s}$ & 33.07 & 1.10 & $24.95 \mathrm{~ns}$ & 32.98 \\
\hline resalk & 1.88 & $0.02 \mathrm{~s}$ & 23.83 & 1.29 & $7.97 \mathrm{~ns}$ & 16.82 & 0.97 & $58.57 \mathrm{~ns}$ & 35.96 \\
\hline PulpY & 1.46 & $1.71 \mathrm{~s}$ & 21.32 & 0.88 & $74.48 \mathrm{~ns}$ & 13.08 & 1.07 & $32.44 \mathrm{~ns}$ & 41.17 \\
\hline kappa & 0.84 & 81.14 ns & 13.27 & 0.98 & $53.05 \mathrm{~ns}$ & 15.94 & 1.09 & $26.85 \mathrm{~ns}$ & 44.81 \\
\hline lignin & 1.38 & $3.74 \mathrm{~s}$ & 16.31 & 2.43 & $0.00 \mathrm{~s}$ & 29.46 & 1.02 & $45.46 \mathrm{~ns}$ & 33.45 \\
\hline wext & 1.30 & $7.32 \mathrm{~ns}$ & 19.97 & 1.05 & $39.43 \mathrm{~ns}$ & 16.50 & 1.37 & $1.40 \mathrm{~s}$ & 43.47 \\
\hline aext & 0.98 & $53.02 \mathrm{~ns}$ & 13.03 & 1.47 & $1.53 \mathrm{~s}$ & 20.18 & 0.82 & $92.61 \mathrm{~ns}$ & 37.68 \\
\hline alfacel & 1.01 & $46.481 \mathrm{~ns}$ & 13.92 & 1.66 & $0.23 \mathrm{~s}$ & 23.52 & 1.05 & $37.95 \mathrm{~ns}$ & 39.00 \\
\hline hemicel & 0.924 & $68.848 \mathrm{~ns}$ & 14.58 & 1.14 & $22.54 \mathrm{~ns}$ & 18.57 & 1.28 & $4.63 \mathrm{~s}$ & 44.70 \\
\hline wfl & 1.20 & $15.69 \mathrm{~ns}$ & 15.89 & 1.76 & $0.08 \mathrm{~s}$ & 23.92 & 1.05 & $37.56 \mathrm{~ns}$ & 37.52 \\
\hline afl & 1.15 & $21.81 \mathrm{~ns}$ & 15.61 & 1.64 & $0.29 \mathrm{~s}$ & 22.85 & 1.05 & $35.99 \mathrm{~ns}$ & 38.45 \\
\hline fw & 1.18 & $18.50 \mathrm{~ns}$ & 15.22 & 1.81 & $0.04 \mathrm{~s}$ & 24.09 & 0.97 & $60.10 \mathrm{~ns}$ & 36.69 \\
\hline coars & 1.07 & $35.53 \mathrm{~ns}$ & 12.86 & 2.46 & $0.00 \mathrm{~s}$ & 30.54 & 0.96 & $60.85 \mathrm{~ns}$ & 34.18 \\
\hline curl & 0.84 & $80.82 \mathrm{~ns}$ & 12.97 & 1.47 & $1.55 \mathrm{~s}$ & 23.39 & 1.39 & $1.00 \mathrm{~s}$ & 43.71 \\
\hline zspan & 1.36 & $4.51 \mathrm{~s}$ & 18.90 & 1.48 & $1.50 \mathrm{~s}$ & 21.14 & 1.19 & $11.39 \mathrm{~ns}$ & 39.17 \\
\hline pilodyn & 1.08 & $33.11 \mathrm{~ns}$ & 13.04 & 1.14 & $19.47 \mathrm{~ns}$ & 21.11 & 1.26 & $6.02 \mathrm{~ns}$ & 46.06 \\
\hline
\end{tabular}
studied traits (table II). On average, the genetic effect

Table II. Analysis of block, family and family $\times$ block interaction.

\footnotetext{
$* r^{2}(\%)$ is the proportion of the variance accounted by the considered term in the model.
} 
Table III. Decomposition of the genetic variance: significance of additive and dominance effects.

\begin{tabular}{|c|c|c|c|c|c|c|}
\hline \multirow{3}{*}{$\begin{array}{l}\text { Source } \\
\text { df } \\
\text { Traits }\end{array}$} & \multicolumn{3}{|c|}{ GCA } & \multicolumn{3}{|c|}{ SCA } \\
\hline & \multicolumn{3}{|c|}{11} & \multicolumn{3}{|c|}{51} \\
\hline & $\mathrm{F}$ & p-value $(\%)$ & $r^{2}(\%)^{*}$ & $\mathrm{~F}$ & p-value $(\%)$ & $\mathrm{r}^{2}(\%) *$ \\
\hline TH_adj & 8.561 & $0.00 \mathrm{~s}$ & 24.78 & 1.869 & $0.05 \mathrm{~s}$ & 13.42 \\
\hline STR & 5.561 & $0.00 \mathrm{~s}$ & 13.80 & 1.326 & $7.07 \mathrm{~ns}$ & 11.51 \\
\hline d & 8.341 & $0.00 \mathrm{~s}$ & 15.88 & 1.009 & $46.03 \mathrm{~ns}$ & 8.83 \\
\hline het & 13.831 & $0.00 \mathrm{~s}$ & 26.15 & 1.16 & $21.68 \mathrm{~ns}$ & 8.77 \\
\hline lignin_adj & 13.404 & $0.00 \mathrm{~s}$ & 23.12 & 1.074 & $34.54 \mathrm{~ns}$ & 10.13 \\
\hline alfacel & 11.44 & $0.00 \mathrm{~s}$ & 24.76 & 0.83 & $79.314 \mathrm{~ns}$ & 10.04 \\
\hline aext & 1.932 & $5.65 \mathrm{~ns}$ & 5.05 & 1.102 & $29.79 \mathrm{~ns}$ & 0.24 \\
\hline wfl & 4.768 & $0.01 \mathrm{~s}$ & 11.54 & 1.25 & $12.22 \mathrm{~ns}$ & 11.22 \\
\hline afl & 1.314 & $0.02 \mathrm{~s}$ & 10.77 & 1.284 & $9.67 \mathrm{~ns}$ & 11.58 \\
\hline fw & 5.532 & $0.00 \mathrm{~s}$ & 10.85 & 0.978 & $52.09 \mathrm{~ns}$ & 9.09 \\
\hline coars & 10.908 & $0.00 \mathrm{~s}$ & 19.91 & 1.017 & $44.46 \mathrm{~ns}$ & 8.46 \\
\hline curl & 8.662 & $0.00 \mathrm{~s}$ & 13.83 & 0.809 & $82.52 \mathrm{~ns}$ & 7.40 \\
\hline zspan_adj & 3.495 & $0.11 \mathrm{~s}$ & 10.18 & 1.524 & $1.51 \mathrm{~s}$ & 13.51 \\
\hline
\end{tabular}

$* \mathrm{r}^{2}(\%)$ is the proportion of the varaiance accounted by the considered term in the model.

accounted for $25 \%$ of the phenotypic variance. For three of the traits (TH, lignin and zspan) showing a significant genetic effect, a significant block effect was also detected; the raw data for these traits were adjusted prior to the decomposition of their genetic variance, (TH_adj, lignin_adj and zspan_adj).

Results of the genetic variance decomposition are shown in table III. Surprisingly, although a significant family effect $(P=1.53 \%)$ was detected for acetone extractives (aext), a non-significant GCA variance $(P=5.68 \%)$ was observed for this trait. This can be explained by the structure of the two models employed for statistical analysis: these used different denominators and degrees of freedom to determine the significance of effects. For the other traits, with the exception of total height (TH_adj) and zspan (zspan_adj) for which significant dominance effects were observed, only additive genetic effects were detected. The GCA variance observed accounting for 10 to $26 \%$ of the phenotypic variation.

\subsection{Genetic control}

Narrow and broad-sense heritabilities and their confidence intervals are shown in table IV. Total height (TH_adj), which is used traditionally as a predictor of growth, had narrow and broad sense heritabilities of 0.456 and 0.727 , respectively. These results underlined, as already demonstrated in the current maritime pine breeding programme, the possibility of obtaining high genetic gains by exploiting dominance as well as additive components of genetic variation.

Apart from lignin content which exhibited a relatively high narrow sense heritability (0.471), the wood quality traits showed generally low to moderate values (ranging from 0.16
Table IV. Estimated narrow sense $\left(\mathrm{h}^{2}{ }_{\mathrm{ns}}\right)$ and broad sense $\left(\mathrm{h}^{2}{ }_{\mathrm{bs}}\right)$ heritabilities (with their confidence interval).

\begin{tabular}{lcc}
\hline & $\mathrm{h}_{\text {ns }}^{2}($ confidence interval $)$ & $\mathrm{h}_{\text {bs }}^{2}($ confidence interval $)$ \\
\hline TH_adj & $0.456(0.321-0.592)$ & $0.727(0.490-0.963)$ \\
STR & $0.231(0.108-0.354)$ & non significant SCA effect \\
d & $0.295(0.167-0.422)$ & $"$ \\
het & $0.509(0.371-0.646)$ & $"$ \\
lignin_adj & $0.471(0.334-0.608)$ & $"$ \\
alfacel & $0.343(0.227-0.458)$ & $"$ \\
wfl & $0.19(0.08-0.299)$ & $"$ \\
afl & $0.172(0.059-0.285)$ & $"$ \\
fw & $0.184(0.071-0.298)$ & $"$ \\
coars & $0.374(0.240-0.509)$ & $"$ \\
curl & $0.249(0.124-0.374)$ & $0.373(0.105-0.642)$ \\
zspan_adj & $0.16(0.042-0.278)$ &
\end{tabular}

Table V. Expected genetic gain for each trait considered independently for a selection intensity of 5\%, genetic gain given in trait units (GG) and in percent (GG\%).

\begin{tabular}{lcc}
\hline & GG trait unit & GG\% \\
\hline TH_adj & 111.63 & 11.36 \\
STR & 4.91 & 28.79 \\
d & 18.65 & 4.51 \\
het & 13.30 & 12.46 \\
lignin_adj & 1.14 & 3.95 \\
alfacel & 0.94 & 2.03 \\
wfl & 0.05 & 2.94 \\
afl & 0.02 & 3.05 \\
fw & 0.23 & 0.81 \\
coars & 0.01 & 6.12 \\
curl & 0.30 & 4.01 \\
zspan_adj & 448.75 & 5.37
\end{tabular}

for zero span to 0.374 for coarseness). Among the wood quality traits, zero span was the only trait for which dominance effects could be used to improve selection efficiency.

\subsection{Expected genetic gains}

Expected genetic gains were calculated for a selection intensity of 5\% (table V). Although high genetic gains (> 10\%) can be obtained for the traditional targeted traits of the maritime pine breeding programme (TH_adj and STR), expected genetic gains are generally lower (less than 5\%) for wood quality traits. Only wood heterogeneity (het) gives expected gains of more than $10 \%$.

\subsection{Genetic correlations and correlated responses to selection}

Amongst those traits for which genetic effects were not significant (table II), non significant or low (most of the time 
Table VI. Phenotypic correlations $\left(r_{p}\right)$ between traits not under genetic control, growth (TH_adj) and density (d).

\begin{tabular}{lcc}
\hline Trait1 & Trait2 & $\mathrm{r}_{\mathrm{p}}$ \\
\hline TH_adj & pilodyn & $\mathbf{- 0 . 1 8}$ \\
TH_adj & resalk & $-0.016 \mathrm{~ns}$ \\
TH_adj & PulpY & -0.11 \\
TH_adj & kappa & $\mathbf{- 0 . 0 9 3}$ \\
TH_adj & wext & $-0.035 \mathrm{~ns}$ \\
TH_adj & aext & $0.067 \mathrm{~ns}$ \\
TH_adj & hemicel & $\mathbf{- 0 . 1 9}$ \\
d & pilodyn & $\mathbf{- 0 . 1 3}$ \\
d & resalk & $\mathbf{0 . 1 7 7}$ \\
d & PulpY & $0.066 \mathrm{~ns}$ \\
d & kappa & $0.041 \mathrm{~ns}$ \\
d & wext & $\mathbf{- 0 . 1 0 8}$ \\
d & aext & $0.001 \mathrm{~ns}$ \\
d & hemicel & $0.083 \mathrm{~ns}$ \\
\hline
\end{tabular}

*ns: not significant at $5 \%$ level.

lower than 0.15) phenotypic correlations were observed with height and density (table VI). Even the correlation between density and pilodyn measurements was low.

Because of the predominance of additive effects for the traits under genetic control, only additive genetic correlations are presented. First, given the importance attributed to fibre properties and wood chemical composition in determining pulp and paper properties, the correlations among these traits were calculated. Then, in order to estimate correlated responses to selection, the outcomes of two strategies were simulated: (1) the consequences of selection for height on wood quality traits; (2) the correlated responses of other wood quality and growth traits to selection for wood density.

Fibre morphology traits (fibre length and width) were highly correlated (table VII). Moreover, strong genetic correlations were observed between fibre dimensions and coarseness (positive correlation) and between fibre dimensions and curl index (negative correlation). Although fibre morphology (length, width, coarseness) was generally independent of wood chemical composition, curl was highly correlated with
Table VIII. Phenotypic $\left(r_{p}\right)$ and additive genetic $\left(r_{a}\right)$ correlations between growth (TH_adj) and wood quality traits, and breeding consequences.

\begin{tabular}{|c|c|c|c|c|c|}
\hline Trait & $\mathbf{r}^{\mathrm{a}}$ & $\mathbf{r}^{\mathrm{b}}$ & $\mathbf{C R}^{\mathrm{c}}$ & $\mathrm{CR} \% \mathrm{i}^{\mathrm{d}}$ & CR 1\% HT \\
\hline TH_adj & 1 & 1 & 111.63 & 11.36 & 1.00 \\
\hline STR & 0.169 & $0.343 \mathrm{~ns}$ & 2.37 & 13.87 & 1.22 \\
\hline d & $-0.192 \mathrm{~ns}$ & -0.48 & -11.13 & -2.69 & -0.24 \\
\hline het & $0.044 \mathrm{~ns}$ & $-0.085 \mathrm{~ns}$ & -1.07 & -1.00 & -0.09 \\
\hline lignin_adj & $-0.053 \mathrm{~ns}$ & 0.395 & 0.44 & 1.53 & 0.14 \\
\hline alfacel & 0.151 & -0.366 & -0.4 & -0.86 & -0.08 \\
\hline wfl & 0.203 & $0.361 \mathrm{~ns}$ & 0.03 & 1.64 & 0.14 \\
\hline afl & 0.278 & 0.795 & 0.03 & 3.95 & 0.35 \\
\hline fw & $-0.048 \mathrm{~ns}$ & $0.064 \mathrm{~ns}$ & 0.02 & 0.08 & 0.01 \\
\hline coars & 0.278 & 0.429 & 0.00 & 2.90 & 0.26 \\
\hline curl & -0.299 & $-0.184 \mathrm{~ns}$ & -0.07 & -1.00 & -0.09 \\
\hline zspan_adj & $-0.057 \mathrm{~ns}$ & -0.432 & -327.27 & -3.92 & -0.34 \\
\hline \multicolumn{6}{|c|}{ 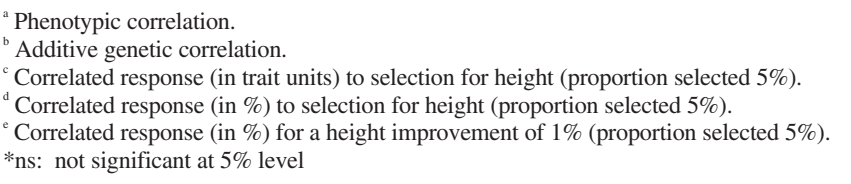 } \\
\hline
\end{tabular}

lignin (-0.54) and $\alpha$-cellulose content (+0.567). Similarly, as found in a study of the maritime pine breeding population (G. Chantre, AFOCEL, France, unpublished) and in Pseudotsuga menziesii [10], a strong negative correlation was observed between lignin and $\alpha$-cellulose contents.

A negative genetic correlation $(-0.48)$ was observed between height and mean density. Thus, selection for growth alone will have negative consequences for solid wood properties, as shown in table VIII. For a $1 \%$ growth improvement, density will be decreased by $0.24 \%$. This type of selection will also have significant impacts on the chemical composition of wood and on fibre properties (table VIII), with an increase in the lignin/ $\alpha$-cellulose ratio, fibre size and coarseness but a decrease in fibre strength.

The correlations obtained between density, growth and wood properties (table IX), suggest that selection for wood density alone would severely decrease growth $(0.97 \%$ growth

Table VII. Additive genetic correlations between fibre properties and wood chemical composition.

\begin{tabular}{|c|c|c|c|c|c|c|c|c|}
\hline & wfl & afl & fw & coars & curl & zspan_adj & lignin_adj & alfacel \\
\hline wfl & 1.000 & 0.752 & 0.619 & 0.763 & $-0.192 \mathrm{~ns}$ & $0.387 \mathrm{~ns}$ & $-0.266 \mathrm{~ns}$ & $0.229 \mathrm{~ns}$ \\
\hline afl & & 1.000 & 0.556 & 0.939 & -0.623 & $-0.032 \mathrm{~ns}$ & $0.141 \mathrm{~ns}$ & $-0.194 \mathrm{~ns}$ \\
\hline coars & & & & 1.000 & -0.766 & $0.052 \mathrm{~ns}$ & $0.122 \mathrm{~ns}$ & $-0.131 \mathrm{~ns}$ \\
\hline curl & & & & & 1.000 & $-0.127 \mathrm{~ns}$ & -0.540 & 0.567 \\
\hline zspan_adj & & & & & & 1.000 & $-0.327 \mathrm{~ns}$ & $0.37 \mathrm{~ns}$ \\
\hline
\end{tabular}

*ns: not significant at $5 \%$ level. 
Table IX. Phenotypic $\left(r_{p}\right)$ and additive genetic $\left(r_{a}\right)$ correlations between density (d) and wood quality traits, and breeding consequences.

\begin{tabular}{lccccc}
\hline & $\mathbf{r}_{\mathrm{p}}{ }^{\mathrm{a}}$ & $\mathbf{r}_{\mathrm{a}}{ }^{\mathrm{b}}$ & $\mathbf{C R}^{\mathbf{c}}$ & $\mathbf{C R \% \mathbf { ~ } ^ { \mathbf { d } }}$ & $\mathbf{C R} \mathbf{1 \%} \mathbf{H T}^{\mathbf{e}}$ \\
\hline $\mathrm{d}$ & 1 & 1 & 18.65 & 4.51 & 1.00 \\
TH_adj & -0.192 & $\mathbf{- 0 . 4 8}$ & -43.10 & -4.39 & -0.97 \\
STR & $-0.017 \mathrm{~ns}$ & $0.101 \mathrm{~ns}$ & 0.56 & 3.29 & 0.73 \\
het & $0.098 \mathrm{~ns}$ & $-0.194 \mathrm{~ns}$ & -1.96 & -1.84 & -0.41 \\
lignin_adj & $0.003 \mathrm{~ns}$ & $\mathbf{- 0 . 5 4 4}$ & -0.49 & -1.70 & -0.38 \\
alfacel & -0.032 & $\mathbf{0 . 6 2 4}$ & 0.54 & 1.17 & 0.26 \\
wfl & -0.229 & $-0.39 \mathrm{~ns}$ & -0.03 & -1.43 & -0.32 \\
afl & -0.2 & $\mathbf{- 0 . 6 7 9}$ & -0.02 & -2.71 & -0.60 \\
fw & -0.285 & $\mathbf{- 0 . 7 6 3}$ & -0.22 & -0.79 & -0.17 \\
coars & $-0.124 \mathrm{~ns}$ & $\mathbf{- 0 . 6 4 9}$ & 0.00 & -3.53 & -0.78 \\
curl & 0.141 & $\mathbf{0 . 6 5 3}$ & 0.21 & 2.85 & 0.63 \\
zspan_adj & $-0.004 \mathrm{~ns}$ & $-0.117 \mathrm{~ns}$ & -71.29 & -0.85 & -0.19 \\
\hline
\end{tabular}

${ }^{a}$ Phenotypic correlation.

${ }^{\mathrm{b}}$ Additive genetic correlation.

Correlated response (in trait units) to selection for density (proportion selected 5\%)

${ }^{d}$ Correlated response (in \%) to selection for density (proportion selected $5 \%$ ).

Correlated response (in \%) for a density improvement of $1 \%$ (proportion selected $5 \%$ ).

*ns: not significant at $5 \%$ level.

decrease for a $1 \%$ density improvement). This type of selection would also result in a decrease of the lignin/ $\alpha$-cellulose ratio, accompanied by a decrease in fibre dimensions and an increase in curl index.

Taking into account the adverse genetic correlations observed among targeted traits (particularly between growth and density), we attempted to define a selection index (table $X$ ). Utilization of the selection index " $\mathrm{A}$ " used currently in the maritime pine breeding programme (simultaneous improvement of both growth and straightness) implies severe reductions in density and $\alpha$-cellulose content and an increase in lignin content (i.e. a depreciation in the trait, since low lignin content is desirable). Modification of the weight applied to density while keeping growth and straightness coefficients constant (index "B"), generated in the best case a close-to-zero genetic gain for growth, an improvement in straightness $(43.71 \%$ of the maximum expected gain for this trait) and an increase in density corresponding to $52 \%$ of the maximum expected gain for this trait.
A maximum increase in density with no consequences for growth (index "C") reduces straightness and increases density by $6.1 \%$, which correspond to $80 \%$ of the maximum possible genetic gain for this trait. Finally index "D", combining constant growth and straightness with a maximum gain in density gave a gain of $5.7 \%$ in density ( $75 \%$ of the maximum possible genetic gain).

\section{DISCUSSION}

\subsection{Genetic determinism of wood quality traits and comparisons with other studies}

For growth, straightness and wood heterogeneity, our estimated heritabilities correspond well with those found in previous studies of maritime pine and other coniferous species (growth and straightness: [12, 14, 31, 65, 67]; wood heterogeneity: [26])

Wood quality traits, including density and fibre properties, showed heritabilities that were generally lower than those reported in the literature. These results can hardly be attributed to the sample size (numbers of families and individuals within each family), which was consistent with samples used in these studies. The high sensitivity of maritime to deviation from verticality and its high within-ring variability in density compared to other conifers can probably explain these results. It is likely that the pronounced basal deviation induces additional environmental effects on maritime pine wood quality. Furthermore, the high within-ring variability in density, which probably reflects a higher sensitivity to climate, may also influence other wood characteristics, increasing environmental variances and consequently decreasing their heritabilities.

Although a significant heritability was found for mean density, no genetic effect was detected for indirect density estimation by pilodyn measurement. Similar results have been reported for Eucalyptus where heritabilities ranging from 0.16 to 0.23 were obtained for density measured indirectly by pilodyn, while heritabilities estimated for density measured on increment cores ranged from 0.67 to 1 [39]. Assessment of density by pilodyn does not seem relevant for maritime pine.

Table X. Index selection optimisation and consequences for "wood quality”.

\begin{tabular}{|c|c|c|c|c|c|c|c|c|c|c|c|c|c|c|c|c|c|c|}
\hline \multirow[b]{2}{*}{ Index } & \multicolumn{9}{|c|}{ Weights } & \multicolumn{9}{|c|}{ Relative gain (\% of maximum genetic gain) ${ }^{a}$} \\
\hline & TH_adj & STR & $\mathrm{d}$ & het & lignin_adj & alfacel & coars & curl & zspan_adj & TH_adj & STR & $\mathrm{d}$ & het & lignin_adj & alfacel & coars $^{b, c}$ & $\operatorname{curl}^{\mathrm{c}}$ & zspan_adj \\
\hline $\mathbf{A}(17)$ & 1 & -17 & $\mathbf{0}$ & $\mathbf{0}$ & $\mathbf{0}$ & $\mathbf{0}$ & $\mathbf{0}$ & $\mathbf{0}$ & $\mathbf{0}$ & 65.27 & 50.91 & -59.98 & -54.69 & -18.74 & -15.57 & 63.98 & -22.13 & -5.37 \\
\hline $\mathbf{C}(30)$ & 1 & $\mathbf{0}$ & 7 & $\mathbf{0}$ & $\mathbf{0}$ & $\mathbf{0}$ & $\mathbf{0}$ & 0 & 0 & 1.15 & -34.16 & 80.60 & 30.06 & 44.39 & 48.30 & -58.03 & 70.00 & -38.78 \\
\hline D (39) & 1 & -9 & 6 & 0 & 0 & 0 & 0 & 0 & 0 & 0.67 & 1.65 & 74.97 & -0.89 & 56.78 & 60.94 & -45.42 & 74.21 & -26.36 \\
\hline
\end{tabular}

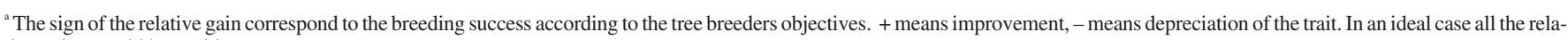
tive gains would be positive.

${ }^{\mathrm{b}}$ According to the genetic correlations observed in table VII, coarseness can be used here as a good predictor of fiber length and fibre width.

c Taking into account our poor knowledge of the consequences of modifying fibre properties for wood quality, increase of those traits were fixed arbitrarily as breeding objectives. 
In agreement with other reports in the literature $[10,11$, $15,19,60,66]$, we observed moderate to high heritability for lignin and holocellulose content $\left(\mathrm{h}^{2}{ }_{\mathrm{ns}}\right.$ (holocellulose) $=0.359$, data not shown). Furthermore, the decomposition of holocellulose into its components allowed us to detect a significant genetic effect for $\alpha$-cellulose but not for hemicellulose. One possible explanation for those contrasting results is the lower level of phenotypic variation for hemicellulose content which did not allow us to detect significant variation among families. Thus, from a tree breeder's point of view, the easiest way to increase cellulose content would be the improvement of $\alpha$-cellulose content. This is also of more industrial interest than an increase in hemicellulose content, since hemicellulose is often removed during the pulping process. Concerning extractives, for which no genetic effect was detected, opposite results were obtained in other species for which significant heritabilities were reported $[13,15,60,66]$.

The lack of genetic control observed for kraft pulping traits (residual alkali, kappa index and pulp yield) despite the agreement with previous results obtained in maritime pine $[26,42]$ is surprising. Indeed, it is inconsistent with the significant heritabilities obtained for lignin and $\alpha$-cellulose contents. The results of this study may be explained by the pulping process itself (kappa number of 30) which could have resulted in a severe degradation of lignin and also of a part of the $\alpha$-cellulose. Indeed, the phenomenon of degradation of the cellulose (peeling effect) can be observed below kappa 35 for maritime pine. This explanation is supported by (1) the lack of a genetic effect for kappa index, which is unexpected given the differences in lignin content between families and (2) the high heritabilities reported for pulp yield in other species. [15]. The values for kraft pulping parameters obtained in this study may be unrepresentative, and should be treated with caution.

\subsection{Integration of wood quality in the maritime pine-breeding programme}

\subsubsection{Interesting single-trait genetic gains are expected}

The main requirements of forest managers and pulp manufacturers can be roughly summarized as an increase in yield and an improvement in wood homogeneity. The heritabilities and phenotypic variation observed for height growth, straightness and density heterogeneity suggest that high genetic gains (reaching 11, 28 and 12\% respectively) could be expected from independent selection for each of these traits.

However, final pulp and paper quality also depends on wood properties. And for traits such as density, wood chemical composition and fibre properties, expected genetic gains are lower $(<5 \%)$. However, given the volume of wood processed each year by the pulp industry and its predicted increase, even slight modifications of these traits could be of commercial value.
Several economic studies $[5,8,37]$, have shown that density has a major impact on mill profits because it affects harvesting, transportation and milling costs. This conclusion is not really applicable to the French maritime pine pulp market where pulp companies buy wood by weight and not by volume. Still, breeding programmes integrating wood density would have great consequences for forest owners' profits, by increasing the mass of wood produced per hectare. Such breeding programmes are impeded by the lack of accurate, rapid and cheap tools for estimating density. In maritime pine, as in Eucalyptus, pilodyn measurements give poor estimates of density. Improvement of wood quality using density as the main target of selection is dependent on the development of new measurement tools.

The influence of density on pulp production and quality has been widely studied, but less is known about the links between fibre morphological properties and kraft pulp production. Horn et al. [24] stated that, for softwoods, there are no relationships between fibre length per se and any one sheet property. Others have shown that tracheid length and tracheid coarseness were the best predictors of costs for thermo-mechanical pulping and high brightness newsprint production [8]. Our results, suggest that improvement of morphological fibre properties is possible, but in order to justify large scale screening, studies will have to be done to define the effects of fibre morphology on kraft pulp production and quality in maritime pine.

Modifications of wood chemical composition and particularly a decrease in lignin content accompanied by an increase in cellulose content would be advantageous in (1) decreasing energy and chemical consumptions per unit of dry wood charged [46, 55] and (2) increasing pulp yield. Our results show that it is possible to obtain this type of result in maritime pine (e.g. -1 and +1 unit respectively for lignin and $\alpha$-cellulose content). In this context the FTIR technique used in the present study may offer some advantages when compared with conventional wet chemistry methods. It is a rapid assessment technique, giving estimates, with reasonable precision, of the chemical composition of small wood samples, hence contributing to a reduction in measurement costs [11].

Although single-trait genetic gains are possible, improvement of the average of one trait will have consequences for other traits, which may in turn have significant impacts on pulp and timber production and quality.

\subsubsection{Relationships between fibre properties and wood chemical composition}

In the literature, fibre properties and the chemical composition of wood are acknowledged to be of great importance for the pulp and paper industries. Comprehension of the relationships between them is thus of primary interest in the development of a breeding programme aimed at improving pulp and paper quality. 
The high positive genetic correlations observed between fibre morphology traits, including fibre length, fibre width and coarseness, suggest that the same set of genes is likely to be responsible for their control, allowing tree breeders to consider only one of the traits in order to improve all of them. The strong genetic correlation between fibre morphology and coarseness is in contrast to the non-significant to low correlation that is generally reported in the literature $[30,45]$. But in one case [45], coarseness was measured in a different way, i.e. using wood density and cell wall dimensions. Therefore, the comparison should be considered with caution. Nevertheless, the positive genetic correlation that was obtained in the present study, is consistent with what is expected if increased fibre length results in fewer fibres per unit volume. The strong negative correlations between curl index and fibre dimensions are probably due to the lower flexibility of wider fibres.

Although Einspahr et al. [15] observed a positive correlation between fibre strength and fibre length in Pinus elliottii, no significant relationships were observed between zero span and the other fibre properties in our study. In maritime pine, genetic control of fibre strength seems to be independent of the genetic control of fibre morphology. Thus, if selection for fibre strength is important for paper properties, it will need to be considered independently of other fibre traits.

The only significant genetic correlations involving wood chemical characteristics and fibre properties were those between curl and $\alpha$-cellulose, and between curl and lignin ( 0.567 and -0.54 respectively). These correlations could be explained by the rigidity conferred on the fibre by the deposition of lignin, though this hypothesis could be confirmed only if, after delignification, morphological characteristics of the fibre are conserved. A link between chemical content and microfibril angle (MFA) would explain the correlations between lignin, $\alpha$-cellulose content and zero span in our study and be in agreement with the findings of Einspahr et al. [15]. Indeed, Chaffey [7] pointed out that the orientation of micro fibrils might well dictate the deposition patterns of lignin and it has been shown that MFA is an important factor in determining the strength properties of individual fibres [47].

In terms of breeding objectives, fibre morphology (length, width, coarseness), physical fibre properties (curl, zero span) and wood chemical composition have to be considered independently. But, as already discussed, the consequences of modifying fibre properties for final end products are not well understood, thus for the present, breeding programmes designed only to improve fibre properties are not appropriate. The main objective of tree breeders will almost certainly remain growth improvement, probably with the integration of wood density as a general selection criterion for wood quality. In the following sections we examine the consequences of selection for growth and density on other wood properties and the possibility of optimising wood quality within a breeding strategy.

\subsubsection{Selection for growth and correlated responses on wood properties}

Today, pulp and paper production account for one per cent of the world's total economic output. There is a rapid and steady increase in demand for pulp products and an increasing shortage of wood supplies. Hence short-rotation intensive culture plantations are now being actively researched as a source of mill furnish [58]. In this situation, one of the mains concerns of tree breeders is the relationship between growth traits and wood properties.

It is generally observed in maritime pine [4], that there is a negative genetic correlation (non significant in our case) between growth and straightness. As a result, selection for height only will result in an increase in basal sweep, which is associated in conifers with a higher frequency of compression wood, an undesirable characteristic in the timber and paper industries.

Unlike Picea (spruce) species, for which a negative genetic correlation is generally reported [52], the relationship between growth traits and wood density is variable in pines. Indeed for maritime pine, positive correlations were found by Polge and Illy [49] and Nepveu [40] while independence of these traits was reported by Keller [26] and Kremer and Nepveu (unpublished). In the present study, a negative correlation between height and density was observed. The differences between the studies can hardly be attributed to maturation effects, since trials giving conflicting results were of almost the same age. One explanation could be the existence of a considerable between and within-population variation for the relationship between growth and wood density in maritime pine. Such variation, partly of genetic origin, was found in Douglas-fir [53].

The absence of a correlation between growth and density heterogeneity has also been reported in other studies involving maritime pine $[26,41]$. Selection of trees combining high growth potential with high wood homogeneity, two of the main requirements of pulp manufacturers and forest owners, is thus feasible.

As in Picea sitchensis, for which Costa E. Silva et al. [11] found a positive (unfavourable) correlation between growth and lignin content, unfavourable correlations between growth (height) and wood chemical composition were observed. Selection for increasing growth is expected to result in extra costs for pulping and lower pulp yields.

In agreement with what is generally reported in the literature, moderate positive genetic correlations between growth and fibre length [19-21,30] and between growth and coarseness [30] were obtained.

It appears that breeding programmes, which aim to improve growth alone, will decrease both timber quality and the efficiency of pulp production. No definite conclusion can be drawn in respect to fibre morphology since objectives vary according to the final product. 
Table XI. Hypothesis testing of the negative additive genetic correlations observed between fibre morphology traits (fibre length, fibre width and coarseness) and density.

\begin{tabular}{|c|c|c|c|c|c|c|c|c|c|c|c|c|}
\hline $\begin{array}{c}\text { Simulation } \\
\text { number }{ }^{a}\end{array}$ & $\mathbf{L d} / \mathbf{C w t}^{\mathrm{b}}$ & $\mathrm{FL}^{\mathrm{c}}$ & $\mathrm{FW}^{\mathrm{d}}$ & Coarseness $^{\circ}$ & $\mathrm{Ld}^{\mathrm{f}}$ & $\mathrm{Cwt}^{\mathrm{g}}$ & $\begin{array}{l}\text { Lumen volume } \\
\text { of one fibre }{ }^{\mathrm{h}}\end{array}$ & $\mathbf{N F}^{\mathrm{i}}$ & $\begin{array}{c}\text { Total lumen } \\
\text { volume }^{\mathrm{j}}\end{array}$ & density $^{k}$ & $\mathbf{r}(\mathbf{d}-\mathbf{f m o r p h})^{1}$ & $\begin{array}{c}\text { Consistency with } \\
\text { our results }{ }^{\mathrm{m}}\end{array}$ \\
\hline \multirow[b]{2}{*}{1} & 3 & 20 & 2 & 5 & 1.50 & 0.50 & 70.65 & 4 & 282.60 & \multirow[b]{2}{*}{$=$} & \multirow[b]{2}{*}{0} & \multirow[b]{2}{*}{ no } \\
\hline & 3 & 10 & 1 & 1 & 0.75 & 0.25 & 8.83125 & 32 & 282.60 & & & \\
\hline \multirow[b]{2}{*}{2} & 2 & 20 & 2 & 5 & 1.33 & 0.67 & 55.8222222 & 4 & 223.29 & \multirow[b]{2}{*}{$\neq$} & \multirow[b]{2}{*}{-} & \multirow{2}{*}{ yes } \\
\hline & 1 & 10 & 1 & 1 & 0.50 & 0.50 & 3.925 & 32 & 125.60 & & & \\
\hline
\end{tabular}

a (1) Identical lumen "diameter/cell wall thickness" ratio. (2) Different "lumen diameter/cell wall thickness" ratio .

"Lumen diameter/cell wall thickness" ratio.

Fibre length given in arbitrary unit.

${ }^{d}$ Fibre width given in arbitrary unit. The values were choosen according to the positive additive genetic correlation observed between fibre length and fibre width (table VII).

'Coarseness given in arbitrary unit. The values were choosen according to the positive additive genetic correlation observed between fibre dimensions and coarseness (table VII).

Lumen diameter deduced from FW and Ld/Cwt.

${ }^{8}$ Cell wall thickness deduced from FW and $\mathrm{Ld} / \mathrm{Cwt}$.

${ }^{\text {h }}$ Lumen volume for one fibre calculated as: $2 \times \mathrm{p} \times(\mathrm{Ld})^{2} \times \mathrm{FL}$.

Number of fibres in a volume corresponding to 20 (length) $\times 4$ (width) $\times 4$ (depth) (in arbitrary unit).

Lumen volume, corresponding to a total volume of 20 (length) $\times 4$ (width) $\times 4$ (depth), calculated as: (lumen volume for one fibre) $\times(\mathrm{NF})$. The bigger the lumen volume is, the lower the density is.

"Density, "=" means identical mean density for the two type of fibres, "f"means different mean density for the two types of fibre.

"Correlation" between density and fibre morphology traits (FL, FW, coarseness) obtained by simulation.

${ }^{\mathrm{m}}$ Consistency between the correlations involving fibre morphology traits and density obtained by simulation, and the correlations obtained in our study .

\subsubsection{Selection for density and its implications for other wood properties}

The economic importance of density as a reliable, easy to measure trait that largely determines the suitability of wood for various end products is widely acknowledged [46]. Nevertheless, it is interesting to evaluate the extent to which selection for density affects other wood quality properties in maritime pine. For timber quality traits, no significant genetic correlations were observed between density, straightness and density heterogeneity. Similar results have been generally reported in various species [6, 11, 26, 34, 49], obliging tree breeders to consider these traits independently in the definition of the selection indices.

Strong genetic correlations of opposite sign were obtained between density and lignin $(-0.544)$ and density and $\alpha$-cellulose (0.624). Similar results were obtained in Picea sitchensis where Costa E. Silva et al. [11] observed a negative relationship between density and lignin content. In spite of the composite nature of density which involved tracheid size, cell wall thickness..., it seems largely explained by the $\alpha$-cellulose content of wood which is negatively correlated with lignin content. It has been often reported that lignin and cellulose content are respectively lower and higher in the latewood $[32,57,61-64]$. However our results did not allow us to conclude to a tight relationship between density and latewood percentage. Indeed, although fibres are longer in the latewood a negative genetic correlation was observed between density and fibre dimensions. In addition no genetic effect was detected for latewood percentage (data not shown). From a practical point of view, the correlations between density and wood chemical composition have interesting industrial implications: selection for increased density would at the same time increase pulp yield and decrease production costs.
Negative genetic correlations were obtained between density and fibre dimensions, consistent with observations reported by Nyakuengama et al. [44], King et al. [30] and Hannrup et al. [20]. A strong negative genetic correlation was also observed between density and coarseness, in contrast to results reported in previous studies [30,44]. As mentioned previously, a comparative analysis should be considered carefully especially with the result obtained in [44]. Nevertheless, the negative genetic relationships found in this study could probably be explained, as shown in the table XI, on the one hand by the lower amount of fibre per unit volume in individuals producing long fibres, and on the other hand by their higher "lumen diameter/cell wall thickness" ratio.

A strong positive genetic correlation, which could be an indirect consequence of the higher flexibility of thin fibres, was reported between density and curl. In contrast, a correlation close to zero was obtained between density and fibre strength. This lack of genetic correlation will have to be considered if density is used as predictor for wood quality breeding.

Breeding programmes using density as the only selection criterion may lead to a severe reduction in height growth, an improvement of the lignin/ $\alpha$-cellulose ratio, a decrease in fibre dimensions and an increase of the curl index of fibres. For breeding purposes, density seems a useful indicator of wood chemical composition and fibre morphology, but a poor predictor of wood heterogeneity and fibre strength. Nevertheless, these results will need to be verified in other trials. Moreover, further studies will have to be performed in order to determine its relationship with commercially important paper properties. 


\subsubsection{Optimisation of breeding for wood quality}

Simultaneous breeding for "wood quality", using density as the main selection criterion, while maintaining levels of gain in the traditional targeted traits is not realistic. An efficient way of integrating wood properties in the maritime pine breeding programme would be the creation of elite populations dedicated exclusively to improving wood quality for particular end uses. The current maritime pine-breeding programme is based on a breeding index including growth and straightness. In this study it is shown that its consequences for wood quality are significant and leads to a strong depreciation of many technological wood characteristics (density, chemical composition). Nevertheless these results can not lead to finite conclusions, further trials will be needed in order to estimate accurately and reliably the genetic control of wood quality and its relationships with other targeted traits. Furthermore, despite the reduction of density, the current selection allows important genetic gain for straightness and therefore in wood homogeneity, two important characteristics for timber and pulp industries.

A two-step procedure for wood quality improvement could be as follows: first selection for straightness and growth will ensure volume production and wood homogeneity; second, specific wood quality traits (e.g. density, lignin content) could be selected from the previous improved population. Genotypes would be selected, depending on the tree breeder's objectives, using index "B" or "D" (table X), which are both conservative with respect to growth. Index " $\mathrm{B}$ " is probably more suitable for timber production, allowing simultaneous improvement of straightness and density $(+43$ and $50 \%$ respectively of their maximum genetic gain). Index " $D$ ", which gives a greater increase in density and thus improves the lignin/ $\alpha$-cellulose ratio is better suited to pulp and paper production.

\section{CONCLUSION}

Our results suggest that breeding of maritime pine trees with outstanding wood quality is feasible. But several points need to be emphasised.

First, although this study allowed us to estimate heritability of several wood properties, these estimations were made for composite traits (total height, mean density, etc.), at a unique maturation stage. No information about maturation effects are available and time trend analysis of height, diameter growth and density components is a necessary future area of study.

Secondly, the correlations between basic wood properties and end product properties are often not well known. Genetic improvement of wood properties is possible, but before they are included as selection criteria in the maritime pine-breeding programme it is essential to determine their effects on the properties of different types of end product. Within the frame of a EU funded project (http: //www.pierroton.inra.fr/Gemini/), this work will be performed through measurements of pulp properties (tear index, burst index...), which have real meaning at the industrial level.

Thirdly, simultaneous breeding for traditional target and wood quality traits is compromised by adverse genetic correlations. As it was shown in this paper, the best way of integrating wood quality in the maritime pine breeding programme is probably the constitution of elite population dedicated exclusively to wood quality with trees selected in a growth-improved population.

Finally, despite the identification of possible target traits for breeding, the diallel analysis provided neither useful predictors for early selection, (it is not possible to evaluate these traits in very young trees), nor the exact genetic architecture of wood quality traits (number of genes, locations, effect of each gene). The latter point is being addressed through QTL (Quantitative Trait Locus) mapping, to identify the chromosomal regions involved in the genetic control of these traits. QTLs should provide not only fundamental information, but also potential early predictors of wood properties, thus avoiding the high costs of traditional measurements and reducing the age of assessment of the traits.

Acknowledgments: This work was supported by funding from the European Union (GENIALITY: FAIR CT98-3953, GEMINI: QLRT-1999-00942).

\section{REFERENCES}

[1] Amstrong J.P., Skaar C., de Zeeuw C., The effect of specific gravity on several mechanical properties of some woods, Wood Sci. Technol. 18 (1984) $137-146$.

[2] Baradat P., Amélioration génétique des arbres forestiers, éléments méthodologiques, INRA, Bordeaux, 1989.

[3] Baradat P., Labbe T., Traitement statistique des essais de sélection, in: Opep. Un logiciel intégré pour l'amélioration des plantes pérennes, Anonymous, Cirad, Montpellier, 1995.

[4] Baradat P., Pastuszka P., Le pin maritime, in: Gallais A., Bannerot H. (Eds.), Amélioration des espèces végétales cultivées, INRA Éditions, Paris, 1992, pp. 695-709.

[5] Borralho N.M.G., Cotteril P.P., Kanowski P.J., Breeding objectives for pulp production of Eucalyptus globulus under different industrial cost structures, Can. J. For. Res. 23 (1993) 648-656.

[6] Burdon R.D., Low C.B., Genetic survey of Pinus radiata, N. Z. J. For. Sci. 22 (1992) 228-245.

[7] Chaffey N., Microfibril orientation in wood cells: new angles on an old topic, Trends Plant Sci., meeting report 5(9) (2000) 360-362.

[8] Chambers P.G.S., Borralho N.M.G., A simple model to examine the impact of changes in wood traits on the costs of thermomechanical pulping and high-brightness newsprint production with radiata pine, Can. J. For. Res. 29 (1999) 1615-1626.

[9] Chantre G., Bouvet A., Sens D., Robin E., Bongrand O., Modeling kraft fiber morphology and paper properties from forest data: the example of maritime pine thinnings logs, TAPPI 2000 Pulping; Process \& Product Quality Conference Abstract Book Boston, 5-9 November 2000.

[10] Chantre G., Rozenberg P., Baonza V., Macchioni N., Le Turcq Q., Petit Conil M., Heois B., Genetic selection within Douglas fir (Pseudotsuga menziesii) in Europe for papermaking uses, Ann. For. Sci. 59 (2002) 583-593. 
[11] Costa E Silva J., Wellendorf H., Pereira H., Clonal variation in wood quality and growth in young Sitka Spruce (Picea sitchensis (Bong.) Carr.): estimation of quantitative genetic parameters and index selection for improved pulpwood, Silvae Genet. 47 (1998) 20-33.

[12] Costa P., Durel C.E., Age trends in genetic control over height and diameter in Maritime pine, Can. J. For. Res. 26 (1996) 1209-1217.

[13] Cown D.J., Young G.D., Burdon R.D., Variation in wood characteristics of 20 year old half sib families of Pinus radiata, N. Z. J. For. Sci. 22 (1992) $63-76$.

[14] Danjon F., Heritabilities and genetic correlations for estimated growth curve parameters in Maritime pine, Theor. Appl. Genet. 89 (1994) 911-921.

[15] Einspahr D.W., Goddard R.E., Gardner H.S., Slash pine, wood and fibre property heritability study, Silvae Genet. 13 (1964) 103-109.

[16] Evans R., Kibblewhite R.P., Lausberg M., Relationships between wood and pulp properties of twenty five 13 -year-old radiata pine trees, $52 \mathrm{nd}$ APPITA annual general conference, CRC symposium fibres beyond 2000, 11-14 may 1998, Brisbane, Australia.

[17] Falconer D.S., Introduction to quantitative genetics, 2nd ed., Longman, London, UK, 1981.

[18] Guignard P., Contrôle génétique du développement de semis de pin Maritime (Pinus pinaster Ait.). Mise en évidence des effets maternels sur la croissance juvénile, Rapport de DEA Univ. Bordeaux II, INRA Bordeaux, 1983.

[19] Hannrup B., Cahalan C., Chantre G., Grabner M., Karlsson B., Le Bayon I., Müller U., Pereira H., Rodrigues J.C., Rosner S., Rozenberg P., Wilhelmsson L., Wimmer R., Genetic Parameters of wood properties in Picea Abies, in: Conference IUFRO Wood Breeding and Biotechnology, June 11-14, 2001, Bordeaux (unpublished).

[20] Hannrup B., Ekberg I., Persson A., Genetic correlations among wood, growth capacity and stem traits in Pinus sylvestris, Scand. J. For. Res. 15 (2000) 161-170.

[21] Hartley L., Nutrients and tracheid length in seedlings of Pinus radiata D. Don., Empire Forestry Rev. 39 (1969) 474-482.

[22] Hatton J.V., Cook J., Kraft pulps from second-growth Douglas fir relation-ships between wood fibre, pulp and handsheet properties, Tappi J. 75 (1992) 137-144.

[23] Hoffmeyer P., The Pylodin instrument as a non-destructive tester of the shock resistance of wood, in: Proceedings of the 4th symposium on non destructive testing of wood, Pullmann, Washington, USA, 1978, pp. 47-66.

[24] Horn R.A., Setterholm V.C., Fibre morphology and new crops, in: Janick J., Simon J.E. (Eds.), Advances in new crops, Timber Press, Portland, OR, 1990, pp. 270-275.

[25] Ivkovich M., Koshy M., Optimisation of multiple trait selection of Western Hemlock including Pulp and Paper Properties, Ann. For. Sci. 59 (2002) 577-582.

[26] Keller R., Caractéristiques du bois de pin maritime, variabilité et transmission héréditaire, Ann. For. Sci. 30 (1973) 63-81.

[27] Kibblewhite R.P., Evans R., Riddell M.J.C., Handsheet property prediction from kraft-fibre and wood tracheid properties in eleven radiata pine clones, 50th Annual General Conference, Auckland, 1996.

[28] Kibblewhite R.P., Bawden A.D., Radiata pine kraft fibre qualities. Toplogs, thinnings, slabwood, and a "genetic misfit", N. Z. J. For. Sci. 22 (1993) 96-110.

[29] Kibblewhite R.P., Uprichard J.M., Kraft pulps qualities of 11 radiata pine clones, PAPRO Report B164, in: Proceedings of the 49th Appita Annual General conference, Hobart, 1995.

[30] King J.N., Cartwright C., Hatton J., Yanchuk A.D., The potential of improving western hemlock pulp and paper quality, Can. J. For. Res. 28 (1998) 863-870.

[31] Kremer A., Déterminisme génétique de la croissance en hauteur du pin Maritime (Pinus pinaster Ait.), Ann. Sci. Forest. 38 (1981) 355-375.

[32] Larson P.R., Changes in chemical composition of wood cell walls associated with age in Pinus resinosa Ait., For. Prod. J. 16 (1966) 37-45.

[33] Larson P.R., Wood formation and the concept of wood quality, Yale Univ. Sch. For. Bull. 74, 1969.
[34] Lee S.J., Breeding strategy for Sitka spruce in Britain, in: Proc. Nord. Group for tree breeding, Edinburgh, Scotland, Oct. 1993, Forestry Commission, pp. 95-109.

[35] Lin C.Y., Index selection for genetic improvement of quantitative characters, Theor. Appl. Genet. 52 (1978) 49-56.

[36] Littleford T.W., Variation of strength properties within trees and between trees in a stand of rapid-growth douglas-fir, For. Prod. Lab. Can. Vancouver, Canada, 1961.

[37] Lowe W.J., Byram T.D., Bridgwater F.E., Selecting loblolly pine parents for seed orchards to minimize the cost of producing pulp, For. Sci. 45 (1999) 231-216.

[38] Megraw R.A., Wood quality factors in loblolly pine, TAPPI Press Atlanta, Georgia, 1985.

[39] Muneri A., Raymond C.A., Genetic parameters and genotype-by-environment interactions for basic density, Pilodyn penetration and stem diameter in Eucalyptus globulus, Forest Gen. 7 (2000) 317-328.

[40] Nepveu G., Étude génétique de quelques qualités du bois de pin maritime. Corrélations avec des caractères de croissance et d'aptitude à l'élagage, Document à distribution limitée, Station de Recherches sur la qualité du bois, 5 (1973).

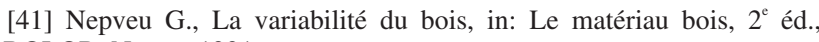
ARBOLOR, Nancy, 1991.

[42] Nepveu G., L'amélioration de la qualité de la production forestière : le cas du pin Maritime, in: Intervention à la $3^{\mathrm{e}}$ rencontre Recherche Formation Professionnels du bois et de la forêt, ENITA, Bordeaux, 13 déc. 1984.

[43] Newlin J.A., Wilson T.R.C., The relation of the shrinkage and strength properties of wood to its specific gravity, USDA Bull. 676 (1919) $35 \mathrm{p}$.

[44] Nyakuengama J.G., Evans R., Matheson C., Spencer D.J., Vinden P., Wood quality and quantitative genetics of Pinus radiata D. Don: fibre traits and wood quality, Appita J. 52 (1999) 348-350.

[45] Nyakuengama J.G., Matheson C., Spencer D.J., Evans R., Vinden P., Time trends in the genetic control of wood microstructure traits in Pinus radiata, Appita J. 50 (1997) 486-494.

[46] Nylinder P., Wood quality and fiber product, in: Proc. IUFRO-5 Meet., Vol. 2, Republic of South Africa, 1973, pp. 832-844.

[47] Page D.H., A method for determining the fibril angle in wood tracheids, J. Microscopy 90 (1969) 137.

[48] Panshin A.J., de Zeeuw C., Textbook of wood technology, McGraw-Hill book Co, New York, 1980.

[49] Polge H., Illy G., Héritabilité de la densité du bois et corrélations avec la croissance étudiées à l'aide de tests non destructifs sur plants de pins maritimes de quatre ans, Silvae Genet. 17 (1968) 173-181.

[50] Polge H., Établissement des courbes de variation de la densité du bois par exploration densitométriques de radiographies d'échantillons prélevés à la tarrière sur des arbres vivants, Ann. Sci. For. 23 (1966) 1-206.

[51] Rodrigues J., Pereira H., Jones G., Cahalan C., Chantre G., Rapid non destructive methods for assessment of wood chemical composition, in: Conference IUFRO Wood Breeding and Biotechnology, June 11-14, 2001, Bordeaux (unpublished).

[52] Rozenberg P., Cahalan C., Spruce and wood quality: genetic aspects (a review), Silvae Genet. 46 (1997) 270-279.

[53] Rozenberg P., Franc A., Bastien C., Cahalan C., Improving models of wood density by including genetic effect: a case study in douglas-fir, Ann. For. Sci. 58 (2001) 385-394.

[54] Rozenberg P., Franc A., Mamdy C., Launay J., Schermann N., Bastien J.C., Genetic control of stiffness of standing douglas-fir; from the standing stem to the standardised wood sample, relationships between modulus of elasticity and wood density parameters, Ann. For. Sci. 56 (1999) $145-154$

[55] Rydholm S.A., Pulping processes, Interscience Publishers, New York, 1965.

[56] Searle S.D., Linear models, New York, John Wiley, 1971.

[57] Siddiqui K.M., Relationships between cell wall morphology and chemical composition of earlywood and latewood in two coniferous species, $\mathrm{Pa}$ kistan J. For. 26 (1976) 21-34. 
[58] Sierra-Alvarez R., Tjeerdsma B.F., Organosolv pulping of wood from short rotation intensive plantations, Wood Fibre Sci. 27 (1995) 395-401.

[59] T273 pm-95, Wet zero-span tensile strength of pulp. Pulp Properties Committee of the Process and Product quality Division, Tappi Press, 1995.

[60] Van Buijtenen J.P., Einspahr D.W., Peckham J.R., Micropulping loblolly pine grafts selected for extreme wood specidic gravity, Silvae Genet. 17 (1968) 15-19.

[61] Von Byrd L., Ellwood E.L., Hitchings R.G., Barefoot A.C., Wood characteristics and kraft paper properties of four selected loblolly pines, For. Prod. J. 15 (1965) 313-320.

[62] Watson A.J., Hodder I.G., Relationship between fibre structure and handsheet properties in Pinus taeda L., Appita J. 8 (1954) 290-310.

[63] Wilson J.W., Wellwood R.W., Intra-incremental chemical properties of certain western canadian coniferous species, in: Coté W.A. (Ed.), Cellular
Ultrastructure of Woody plants, Syracuse University Press, New York, 1965, pp. 551-559.

[64] Wu Y., Wilson J.W., Lignification within coniferous growth zones, Pulp Pap. Can. 68 (1967) 159-164.

[65] Zhang S.Y., Morgenstern E.K., Genetic variation and inheritance of wood density in black spruce (Picea mariana) and its relationship with growth: implications for tree breeding, Wood Sci. Technol. 30 (1995) 63-75.

[66] ZhiChun Z., GuangRong L., GuangLin H., BingXing C., YaoKe L., Genetic control of wood chemical composition and its implication for wood breeding of Masson pine, Scientia Silvae Sinicae 36 (2000) 110-115.

[67] Zobel B., Jett J., Genetics of wood production, Springer series in wood science, Springer-Verlag, 1995.

[68] Zobel B.J., Buijtenen J.P., Wood variation: its causes and control, Springer-Verlag, 1989.

To access this journal online: www.edpsciences.org 
